\author{
JULIA M. MURRMANN \\ University of Warsaw, Warsaw, Poland \\ https://orcid.org/0000-0003-0043-6640
}

Copyright and License: Copyright by Instytut Języka

Polskiego PAN, Kraków 2021. This article is published under the terms of the Creative Commons Attribution - NoDerivatives 4.0 International (CC BY- ND 4.0) License (https:// creativecommons.org/licenses/by-nd/4.0/legalcode.pl).

\title{
EFFECTS OF THE COVID-19 PANDEMIC ON MULTILINGUAL FAMILIES FROM A SOCIOLINGUISTIC PERSPECTIVE
}

Keywords: multilingualism, lockdown, COVID-19 pandemic, language competences, family.

\begin{abstract}
The unprecedented situation caused by the sudden worldwide spread of the novel coronavirus, with the introduction of safety measures as a consequence, changed many aspects of life of families raising children multilingually. With empirical data from 157 international families interviewed via an online survey, in the present paper, we addressed the significant repercussions that the COVID-19 pandemic brought to their daily routines from a sociolinguistic perspective and investigated their use of languages during the lockdown(s). As for a preliminary evaluation of the impact of the safety measures on the linguistic situation at home, according to 68 families the COVID-19 pandemic had generally a positive influence on the knowledge and distribution of languages spoken by children, 49 observed an overall negative effect, 33 interviewed families said that there were no significant changes in their households due to the COVID-19 pandemic, and 7 respondents admitted that it was still too early to assess the consequences of the global health emergency on their language situation at home. It should be highlighted that different families adopted different strategies to cope with the new circumstances caused by quarantining, lockdowns, stay-at-home orders, prolonged self isolation, social distancing, school closures, switching to remote learning, travel bans, and other restrictions. In many cases it was necessary for the parents to introduce a new family language policy, to implement new strategies, to use alternative and additional educational resources, to find solutions to new challenges, needs, tasks, and difficulties emerged under the new circumstances. Based on the research outcomes it was possible to gather advice, recommendations, good practices, helpful ideas and valuable tips voiced by the interviewed parents. The findings of the study may be of theoretical interest to linguists researching different aspects of multilingualism, and of practical interest to parents growing or planning to grow a multilingual family.
\end{abstract}

\section{INTRODUCTION}

The outbreak and spread of coronavirus disease 2019 (COVID-19) and the consequently resulting introduction of several safety-related restrictive measures and protocols (travel restrictions, gathering bans, and general closure of schools, child care centers, and many public institutions and businesses), and finally lockdowns (or quarantines, stay-at-home-orders, shelter-in-place, and social isolation recommendations, depending 
on the terminology adopted in different parts of the globe), brought an unprecedented change to the daily lives of families all over the world. Researchers representing different fields of study have started to examine the first effects of the pandemic, including economic, social, psychological, and health perspectives. An interesting study was carried out in Italy, the first country heavily hit by the pandemic outside of China, on parents and children during the COVID-19 lockdown with the focus on the influence of parenting distress and self-efficacy on children's emotional well-being (Morelli, Cattelino, Baiocco, Trumello, Babore, Candelori, Chirumbolo 2020). Results based on an online survey completed by 277 parents of children aged 6 to 13 years revealed how parents' belief in being competent in managing tasks might be a protective factor for their children's psychological needs and mental health.

In this paper, we wish to address the topic of the impact of the COVID-19 pandemic on the situation of the multilingual families from a sociolinguistic perspective. Research on multilingualism has been receiving much scholarly attention in recent years and has been spreading in numerous directions (Ceroz 2013, 3). Indeed, most of the world's societies are plurilingual ${ }^{1}$ (Bhatia and Ritchie 2013, xxi; Edwards 2013, 14; Franceschini 2013, 5; Spolsky 1998, 51), and the phenomenon of multilingualism is being studied and approached from different scientific perspectives (Stavans and Hoffmann 2015). Wide-ranging studies with different scopes and objectives provide a better understanding of contemporary multilingualism from numerous points of view. Family multilingualism has already been studied in many contexts and the topics of changing a family language policy, adopting a strategy, or introducing a new method due to circumstantial factors, such as relocation (with a new community language being added to the family's repertoire), parents' separation, arrival of the siblings, etc., have been widely addressed, ${ }^{2}$ but remained a micro-level occurrence. Now, however,

\footnotetext{
${ }^{1}$ It must be, however, stated that the terms 'plurilingualism' and 'multilingualism' can be interpreted in several ways and the phenomenon standing behind them has many ambiguous aspects and forms (Cenoz 2013). It is even, for example, unclear what degree of proficiency is needed in the language to be recognized as a mother tongue and how many languages are considered necessary to talk about 'multilingualism'. The mainstream position holds that 'multilingualism' is a generic term in opposition to 'monolingualism' (Aronin, Singleton 2008), but some researchers prefer to distinguish between the term 'bilingual' for users of two languages and 'multilingual' for users of three or more languages, which is consistent with the literal meaning of Latin prefixes bi ('two') and multi ('many'). For the purpose of this study and its methodological premises, we think that focusing exclusively on an individual and not on a societal, socioeconomic or geopolitical level, the maximal difference can be spotted between the use of one language in a household (monolingualism) and the use of more than one language (bilingualism and multilingualism), regardless of the fact how many languages exactly are being actually spoken (two, three or more). Therefore, in the present paper we will use 'multilingualism' as a hypernym that includes 'bilingualism', 'trilingualism', 'quadrilingualism', etc. By no means are we prone to see these terms as synonyms, nor are we using them interchangeably, but - as this 'lack of precision' does not produce any misinterpretation of the research data - we choose to see the dual language competence as subcategory of a more comprehensive umbrella term.

${ }^{2}$ For insights on variety of strategies, methods and techniques (those basic and those modified) available to parents interested in raising their children with more than one language, see Murrmann 2019; Zurer
} 
we are witnessing a macro-level phenomenon of a unique dimension and it may be for the first time in history, due to these unexpected, new social circumstances, that these issues concern multilingual families on such a large scale and to such a huge extent.

In our literature review, we did not encounter any study based on the same principles and aiming at the same research problem as the present investigation. It is, however, to be expected that many scholars (and groups of researchers) are already focusing, or will soon dedicate, their attention to this particular turning point in the history of family multilingualism. Some time is needed to gather data, to elaborate upon it, and to get the review and publishing process started. We are aware of an extensive study led by Ludovica Serratrice and carried out by a group of researchers at the University of Reading, the University Oxford, the University of Cambridge, the University College London, and other institutions, surveying the language habits of over 700 multilingual families in Britain and Ireland (which next to English reported using 95 different languages) from April to July 2020, so during the time when these countries were mostly shut down ${ }^{3}$. A group of scholars at the University of Oslo led by Elisabet García González and supervised by Elizabeth Lanza, conducted an adapted version of the same survey, collecting responses from almost 200 families in Norway. The parents in those families spoke more than 40 different mother tongues, including French, Polish, Spanish, Hindi, Punjabi, Urdu, Kirundi and Zulu. Before the lockdown, the children tended to use the dominant languages: English in Britain and Ireland, and Norwegian in Norway (plus English, thanks to television, computer games and other media). Preliminary data suggest that children (especially younger) were using the parents' languages more often during the lockdown. The projects are supposed to be continued and such a longitudinal study can be a great contribution to the field of study in question. Moreover, there are many posts on private blogs and social media, interviews with specialists and therapists, para-scientific elaborations, case studies and autobiographic contributions addressing

Pearson 2008; King and Mackey 2009; Barron-Hauwaert 2011; Baker 2014; Festman, Poarch and Dewaele 2017; Braun and Cline 2014; Wang 2008, 2016.

3 "In early April, together with colleagues from the Centre for Literacy and Multilingualism at the University of Reading, and colleagues from UCL, Oxford, Cambridge, Mother Tongues and WeLiveLanguages, we launched a survey for multilingual families in the UK and Ireland. The lockdown was an unmissable opportunity to see how more time at home with immediate family and the shift to virtual communication with extended family, friends, and school might change the use of English and other family languages. The study remained open until July and we were overwhelmed with the response. What emerged from a preliminary analysis of the survey data is that parents did not seem particularly concerned that the lockdown would negatively impact their children's spoken English; however, parents of younger children seemed somewhat more apprehensive than parents of older children. Parents reported that children across all ages had more opportunities to hear their other languages than before lockdown, and this was particularly noticeable for pre-school and primary school age children. Younger children - especially primary school children - were also more likely to speak the other languages more during lockdown than before. Some parents also reported an increase in reading in the other languages. Overall parents perceived a shift towards more opportunities to hear and use the other languages during lockdown, particularly in the case of younger children, but there was also a considerable amount of variation" (Serratrice 2020). 
the effects of the pandemic on multilingual families easily found by just browsing in Internet (Hardach 2020).

\section{RESEARCH OBJECTIVES AND METHODOLOGY}

With data from international families, we investigated the reality of life in multilingual families during the lockdown(s). The empirical data was gathered via an online survey in February 2021, which is 10-11 months after the novel coronavirus had first started to change the face of daily life worldwide. The respondents were contacted through private thematic groups on social media platforms dedicated to the 'multilingualism', 'multilingual parenting', 'bilingual upbringing', 'expat life', 'living abroad', 'GermanEnglish bilingual children', and 'world-children', using different social networks: Facebook, Instagram, WhatsApp, and recruited through a snowball sampling procedure to complete the online survey (parents were asked to share the post among their contacts). Overall, 157 families (F1 - F157) successfully participated in the study. The collected material was content-analyzed and trustworthiness criteria were applied. The data was processed by use of basic office software program Microsoft Excel and Atlas.ti for quantitative analysis of textual data.

We had the following research questions in mind:

1) What is the initial overall assessment of the effects of the COVID-19 pandemic on the family language situation, particularly with regard to observations about children's linguistic competences?

2) How did families adjust (and continue to adjust) to the new circumstances created by the spread of coronavirus?

3) Where did multilingual families find help, support, and resources during the pandemic?

4) What are the expected long-term effects of the COVID-19 pandemic for multilingual families?

5) What recommendations, good practices, and valuable tips can be given to the multilingual families struggling under these new circumstances?

There are important research and conclusions limitations. It should be stressed that there are many factors that influence the outcome of the study. The sociolinguistic circumstances across the interviewed families were (and still are) extremely varied, both endo- and exogenously: country (region/state/city) of residence which results in different protocols and pandemic-related restrictions to be obeyed; schedules of closures (due to stage of the pandemic, seasons, and waves of infection rates); duration and type of lockdown and child care/school offered at that time - in-person instruction, remote learning, hybrid/blended systems, ${ }^{4}$ etc.; individual approaches to the virus and disease;

\footnotetext{
${ }^{4}$ Even within the same country, the regulations may differ significantly across the regions, states, or cities. Even within localities, there were varied school system policies coexisting, often depending on the type of the school: public, charter, private, catholic, etc.
} 
family health, with or without preexisting conditions; family dynamics (newborns or pregnancy); family composition (co-living grandparents, infants, handicapped members of the family, size of the family, number of siblings); age of children and their developmental stage (preschool age, starting the school experience, or with many years of education already); homeschooling even without lockdown; linguistic competences of the parents and children in a given language. No research can claim to fully control the variation factors mentioned above - each family is different, may evolve over time and as family circumstances and dynamics change. To briefly illustrate the socio-demographic, cultural and linguistic variety of the study sample, we can state that the 157 families (F1 - F157), which participated in the study, come literally from all over the world (with 67 different countries of origin and 42 different countries of residence), speak at least 35 different languages (not including regional dialects), have currently a total of 339 children (31 families with 1 child, 79 families with 2 children, 39 families with 3 children, 4 families with 4 children, 1 family with 5 children, 2 families with 6 children; most children were in the age 2-16). In this context it is also important to stress that by 'family' we understood in the present paper a group of persons united by the ties of marriage, partnership, blood, or adoption, and constituting a single household. We had traditional nuclear, monoparental (divorced), rainbow, extended (with co-living grandparents), patchwork and blended families in the study group.

\section{STUDY RESULTS}

\section{Overall assessment of the effects of the COVID-19 pandemic on family language situation}

The interviewed families were asked to evaluate their linguistic situation at home in light of the COVID-19 pandemic and their assessments can be presented as four main categories:

1.1. The COVID-19 pandemic had generally a positive impact on the language situation at home $(n=68)$;

1.2. The COVID-19 pandemic had an overall negative effect on the language situation at home $(\mathrm{n}=49)$;

1.3. There were no significant or no changes at all in the linguistic situation at home due to the COVID-19 pandemic $(n=33)$;

1.4. It's too early or impossible to assess the consequences of the COVID-19 pandemic on the language situation at home, as all remains very unstable and shifting from one extreme to the other $(n=7)$.

In the first group of parents (1.1), the newly achieved distribution of languages at home is evaluated positively as the lockdown brought (or restored) the balance between the languages in family's repertoire and helped to support the acquisition of the previously less spoken language(s), which was most often the minority language versus the 
better known community language $(n=43)$. More (quality) time with the children at home resulted in more exposure to the previously less spoken language. In other words, for these families, the pandemic meant a return to their native (heritage) language(s). Children replying traditionally in a majority language to the utterances in minority language(s), with the COVID-19 upheaval, were forced to stay inside and isolated and this situation reshuffled the linguistic pattern. Children are hearing more of their parents' mother tongue(s), and the previous domination of the preferred community language is shifting towards a peaceful coexistence between all languages in the family's repertoire. Several parents reported that the kids "embraced a previously almost hated or forgotten language with unprecedented enthusiasm" (F34, F113), "showed a sudden interest in a language not spoken for years" (F34), "started engaging more and more with the second language" (F7), that the "heritage (minority) language started to blossom" (F11, F35, F66, F100, F143), that "all of the sudden the minority language became a preferred language and they observed a sudden rejection of the previously dominant (country's) language" (F22), that "there were now two favorite languages to communicate in" (F101), that "a radical switch to the previously hardly spoken language was observed" (F66), and that "the second language took off, finally, after years of unsuccessful trials" (F51). Even the fact that assisting children with schoolwork is now mostly occurring with mixed languages (school language and home language) is seen positively as new vocabulary needs to be added to cover areas that were rarely addressed before. As a consequence, children learn new structures in a minority language (that they probably wouldn't have learned otherwise!), see the language uses, variations, and contexts they haven't considered before, use those languages flexibly and interchangeably according to the situation, and, last but not least, begin perfecting translations from one language to the other. Moreover, some parents admit to have expanded their knowledge of the majority (school) language, which is not their mother tongue, in certain earlier unexplored fields, and also to have practiced "translanguaging", translating, and code switching. They confess to be happy to be able to help their offspring develop in so many areas and aspects, including linguistically.

In the second group (1.2) the distribution of the languages in the household suffered due to the fact that the use of the community language (not spoken at home under normal circumstances because the family chose the 'minority language at home'-strategy) decreased acutely and its acquisition is not sufficiently supported $(n=30)$. Remote learning is, understandably, not fully the same as in-person classes (especially if the competence in the school - and local - language is not excellent). The situation becomes even more problematic if none of the parents speak the (local) school language (as F78), and so a tutor's virtual help becomes indispensable. Many families missed play dates and organized activities that previously ensured input from the majority language. Again, FaceTiming, Zoom-parties and Google-meet appointments are not the same as in-person meetings. Even the outdoor options for socializing remained limited because, in many regions, the use of playgrounds was prohibited. Another reason for the negative evaluation is the fact that the travel bans and restrictions rendered it impossible to visit a home country 
where the minority language is spoken $(n=25$; some parents listed more than one reason for their negative evaluation). F13 confessed: "Travel restrictions resulted in the lack of the total immersion in German over the summer which used to be for us a perfect way to balance the languages at home and a chance to charge linguistic batteries". The shutdowns for international tourists prevented the grandparents, relatives, or au-pairs from coming to visit $(\mathrm{n}=8)$, or at least suspended the in-person contacts and face-toface conversations with the members of the family that were previously an important source of input in a minority or third language $(n=6)$. Many multilingual families rely heavily on their extended family's support: relatives take an active role in the children's lives and linguistic and cultural development. Some families remained separated (for a shorter or longer period of time) by the overnight introduction of international travel restrictions $(n=4)$. For F3, the COVID-19 pandemic coincided with a work deployment overseas, so she and her husband were separated for months, which left her daughter with no face-to-face interactions in the second language. Similar to school activities, most speech therapy centers were forced to switch to virtual sessions, which are less effective than in-person lessons according to the parents, especially where toddlers are concerned. Some parents also faced newly emerging problems with children, of socio-emotional, behavioral, and linguistic nature. One mother (F91) reported an onset of a speech disorder like stuttering, another observed that separation anxiety became severe, and another reported an emersion of a strange and recurring difficulty in expressing in any language at all. Some respondents $(n=8)$ said that their native tongue, previously successfully used for the communication at home ('minority language at home' method), was suffering because they were obliged to home-school the children in the country's dominant language (they still mixed, but very often they had to focus on educational resources and academic issues available in the local school language by suppressing the second language). Undesirable language mixing therefore happened much more often, and in many cases code-switching occurred on daily basis. F27 is frustrated because, "The situation at home became very chaotic. Before we had much clearer rules and patterns, now all is mixed up and we ended up code-switching and mixing". A possibly positive aspect in this context seems to be the fact that the waves of infections and subsequent lockdowns were spread across two different academic years: first starting mid March-early April depending on the place (so shortening the 2019/20 academic year by 2-3 months only), and then the second school closure happened, depending on the location, at some point after the 2020/21 academic year had already started, taking away bigger or smaller portions of the in-person instruction. Also, after the summer break, the teachers and school staff were all much better prepared for the upcoming challenge of eventually switching to remote learning again. Some schools had longer winter breaks in the Catholic Christmas time and winter break, and many countries resumed some in-person classes at different times. So the periods of school closure were divided in stages, which is to be seen as a positive aspect as it facilitated alternating the use of the languages.

The third case (1.3) regards mostly the families with very small children who are not yet concerned by school duties $(n=17)$, and the families that homeschooled (or 
unschooled or world-schooled, according to recently emerged trends and terminology) prior to the COVID-19 pandemic and regardless of it $(n=5)$. Some parents $(n=7)$ simply did not observe much change. Respondents from Australia, Sweden and Norway did not see any changes, apart from compulsory mask wearing, because of fewer restrictions, and schools and childcare remaining open. For F68 nothing changed because the remote-learning fully replaced and compensated for the traditional in-person school and at home they were able to maintain the other two languages in status quo.

The fourth group (1.4) was even harder to identify as such, but the main point stressed by the parents was the instability, unpredictability, and insecurity of the current situation. The circumstances constantly changed with the first and second wave of infections followed by frequent school closures and re-openings, with seasons (enabling more or less socializing outdoors), with the subsequent changes of strategy adopted and re-adopted at home as an attempt to re-balance the changing external circumstances, and finally with typical and universal stages in social, emotional and linguistic development, phases in learning and especially curved and non-lineal language acquisition seen in multilingual children in different ages regardless of COVID-19 lockdowns.

\section{Family adaptations at home amid the COVID-19 pandemic}

With the onset of the pandemic and the introduction of restrictive safety measures, all families were left on their own overnight and had to find an effective way to function under those new circumstances. In an instant, many parents necessarily stayed at home, switched to home office and started smart-working (unless they were considered essential workers), and were put in the situation of becoming full-time caregivers to their offspring, which involved providing a wide spectrum of help and assistance to their children, including new tasks such as general homeschooling next to the ever-present and ongoing endeavor of a multilingual upbringing. Children were suddenly deprived of their daily routine that provided not only educational, sport, and leisure activities, but also basic socialization, play time, friendships, interactions with peers, and relational contacts with the teachers and caregivers. Some families $(n=21)$ were able to bring an extra help to live in with them, like a grandparent or other relative, which represented both linguistic and extralinguistic advantages to family life in lockdown. If no external help could be provided, the parents were trying to adapt to the new situation and share the newly added duties between themselves.

Linguistically speaking, the most common reaction to the pandemic was to change the family language policy $\left(n=102^{5}\right)$. Many families chose to try to introduce a different language strategy than they were using prior to the COVID-19 restrictions. This was dictated by the individual situation in a given household and according to the personal needs in a given family. Therefore, the changes had many different variations, but four main groups can be isolated as follows:

\footnotetext{
${ }^{5}$ The rest of the families $(n=55)$ did not change their language policy at home.
} 
2.1. One parent changed the language of the main communication with the child/ children $(\mathrm{n}=36)$;

2.2. The family language (used when the family spends time all together) changed $(n=30)$;

2.3. One or both parents chose to start to mix the use of languages at home, abandoning previously used OPOL-method and turning to language switching according to the temporary needs, which had several similarities to context/time and place method ( $n=29)$;

2.4. The use of a certain language was temporarily abandoned for the sake of a pleasant atmosphere at home, resulting in switching to a common language $(n=7)$.

It should be noted that the effort of strategy changing cannot be unambiguously associated with the assessment of the effect of the pandemic on the language development in children: F43 declared that they changed the strategy as in category 2.1 and they still note the negative impact of the pandemic on their language situation (probably because the father is not a native speaker of the language he chose to switch to; it is undoubtedly difficult to become an overnight linguistic role model in a non-mother tongue), while F12 adopted a new strategy (2.2) and their overall impression of the consequences of the lockdown are generally very positive (most likely because the whole family is multilingual with high proficiency in all spoken languages). F41 found themselves in a completely new situation following the lockdown, with both parents working from home and the use of the 'mother-children only language', resulting in many stressful situations (it was not understood by father), so the strategy 2.4, which was switching to the whole-family-language, brought significant improvements and the overall evaluation of the COVID-19 pandemic is positive. It was simply accepted that the mother-children interactions will be held in the whole-family language for the time of the stay-at-home-period. In fact, these situations also happened occasionally before the pandemic for the same family, because the mother actually distinguished between using one language at home and another in public to make her communication with her children understandable for all interlocutors. Now, it's just a "temporary solution before the things get back to (new) normal".

These artifacts - as it may seem at first glance - just show that the final outcome is strictly correlated to the family situation, their pre-chosen and adapted language policies, and linguistic competences.

\section{Help, support, and resources available for multilingual families during the COVID-19 pandemic}

We already described above that with the outbreak of the COVID-19 pandemic, the parents found themselves in the difficult situation of managing their children at home 24/7, starting smart-working from home, and still having an eye on their children's school commitments. With shelter-in-place and stay-at-home orders, the world shrunk down to the immediate family members. Some families said that the very first period 
felt like an extra vacation as everybody was just at home and observed the turn of the events. Soon, it became clear that the health emergency was real and the situation serious. With schools and childcare centers closed, the parents became truly responsible to provide (learning) activities to their children and include in their working (provisory) 'curriculum' a balanced development of all languages of the child's repertoire. It was difficult to search information and support in scientific sources and guides, as evidently this was a fully new circumstance in our modern world. However, as reported by several families participating in the study, multiple online resources were created almost overnight. Plenty of websites managed by different organizations, institutions, language centers, and schools (available in different languages) provided free materials, ideas, and guidelines for parents to facilitate learning at home. Private bloggers and influencers shared interesting educational resources to work with (these were shared in the groups on social media). Additionally, dedicated groups on social media were created and offered new insights and possibilities. Many initiatives were also initialized by the parents themselves - instead of face-to-face play dates and meetings they started to organize Zoom or Google meet-parties, and virtual playgroups. Television, Netflix and Youtube videos were often used to fill in the time (especially if parents needed to focus on their professional commitments). Most respondents ( $\mathrm{n}=124$; to a different degree) admitted that during the COVID-19 lockdowns, their children's screen time increased significantly but a bright side of this solution was the possibility to keep different languages alive and active. Moreover, the screen time not only included watching cartoons and films on television, but also reading audiobooks and working on educative programs. Many internet-based, free learning platforms were offered for children to practice counting and reading. Websites packed with DIY art projects and science experiments were broadly available, often with a free trial time. Within a short period of time, numerous commercial initiatives with attractive learning supplies took off (viewable on screens or printable). Some parents found engaging online art and music classes. Still, these, along with sport classes and all other virtual meetings, are to be considered 'screen time'.

Several parents mentioned that the closed-to-the-public libraries offered virtual reading appointments for toddlers. Teachers were sending additional academic materials with which to work. The power point presentations were to be completed online, but many handouts were printable.

Many parents found some help with their relatives. If physically absent, they were often asked to FaceTime, Zoom, Skype or WhatsApp with the children just to fill in some time. The role of grandparents in this position was highly appreciated.

\section{Long-haul perspective on the effects of the COVID-19 pandemic for multilingual families}

The research outcome in this area is often of a hypothetic nature and can be presented as the following findings. Parents admit that they have learnt a great deal about the parent-child relations and gained an unforgettable experience from the unexpected 
extra quality time (which was often difficult and stressful, because most parents had to juggle between providing education and care at home, working professionally, and handling household chores, but all-in-all it was nolens volens a time with and for the family). This is an interesting extralinguistic aspect: many highlighted that the periods of quarantine brought them closer together as a family. With no peer friends, the parents (and siblings) became the most important point of reference, the world previously composed of many agents shrunk down to just the immediate family members. Therefore, the core family strengthened the bonds. This was a valuable lesson about a new type of family functioning. Many admitted that the new parental resources, know-how, good practices, and experience gathered during the lockdown will actually pay off in the future relations with their little and young ones.

Parents declared that they had to engage in more home learning (or para-learning) activities with their children during the lockdown than they ever did before the pandemic. It was either their absolute duty or their choice to keep the children entertained, to never hear "I'm bored" (F30) and "to survive" (F45). They read more books with their children, spent more time together in nature (nature walks, short trips), played more (board) games, did more puzzles, (re)discovered arts and crafts, (re)started forgotten hands-on activities, cooked, and baked more together with children to make it seem a fun activity.

As time passes, parents tend to feel more familiar with the new situation, and are more confident about their own skills in managing the new situation and tasks.

As for a strictly linguistic perspective, it is still very early to predict what will happen. Expectedly, the group of parents which was positively evaluating the family language habits at home from the moment that the pandemic started (1.1) is more optimistic than the groups that are already upset with the changes (1.2), that didn't note any changes (1.3), and that feel very insecure under the constantly changing circumstances (1.4). The first part hope that there may be long-lived positive changes and that their children actually took linguistic advantage of the pandemic. Even if some habits go back to the pre-COVID-19 hierarchy, the previously less spoken language(s) improved within this extra almost one year of time. In other words, even after the return to (new) normality and school reopening, the dominance of the majority language may not be as evident as before. And, it is not excluded that the new balance between the earlier evidently first (dominant) and second language will be still kept in place. Time will tell. With a consistent involvement from parents, this scenario is quite plausible.

The rest of the parents (with some exceptions) tend to highlight the negative repercussions, and their vision of a future of balanced mastery of the languages is to be seen in darker colors. Some parents are truly concerned that "the time window to become a native speaker [in this very case - Turkish] irreversibly closed" (F103), "there is an irreparable damage to the local language without in-person support of native speakers" (F77), and that "we will always see deficits in (language) development of the children due to this self- isolation period" (F92) [it is not clear if this explicitly and specifically regards the multilingual competence]. Nevertheless, some parents still hope that this experience may actually have a long-haul positive impact on raising children multilingually. 
Even if the language competences in the local language suffered compared to the home language(s), this can still reverse with the comeback of the (new) normality, return to the activities and events in the local community, and school reopening. Then, the improved competences in the minority language may be a positive leftover of the difficult time passed, like a "silver lining" (F33), "a surprising side-effect of the pandemic" (F67), "unexpected benefits of the quarantine" (F51, F55), "possibly the only bonus of COVID-19" (F154).

\section{Recommendations, tips, and good practices to share with other multilingual families}

Assuming that nobody can really know how long we will have to deal with several restrictions, bans and limitations during this pandemic, and also it cannot be fully ruled out that there will not be a next health emergency with comparable dimensions, associated with a natural or man-made crisis or disaster, parents were asked to formulate some recommendations, helpful strategies, and tips that can be shared with other multilingual families still struggling under these new circumstances. Again, each family is different, there is no one fit solution for all, and everybody handled the situation in a little different way, often by means of trial and error. However, at some point, one way or another, important lessons have been learned, new ideas or projects emerged, and some conclusions can be drawn after an almost one-year-long experience of life as a multilingual family with COVID-19 in the background.

Most parents disregarded the 'multilingual aspect of the question' and stressed that the most important thing to keep in mind during the experience of seclusion and self-isolation was to care for the psychological well-being of the children. "If the kids are happy, all is easy. Each activity works for them. Keep them happy", sounds the solution according to F23. "Just try to enjoy this time", said F76. Parents' positivity, faith, and warmth were highlighted. The role of parents is almost like that of leaders in a company or during turmoil - to lift the spirits, to provide comfort, to bring cheer. Less pressure, less rush and fewer expectations, tolerance and simply capacity to accept delays or troubles with some tasks, including the linguistic performances, in the educational process were advised. Patience is needed to find a new balance, and a new working routine. The screen time, Internet and television should be used wisely and not too extensively as it only apparently engages children (especially those young). In many cases, parents stressed that it was a "double-edged weapon" ("two-edged sword") because of the unbearable behavioral reactions after the screen-time sessions were over: crying, emotional outbursts of anger, uncontrolled frustration, acting out, tantrums (F5, F19, F41, F59, F61, F81, F123, F130, F139). Some parents also fear the technology addiction and digital media, which in long term perspective could potentially result in compulsive behaviors, mood disorders, compromised attention/concentration, negative repercussions to physical and mental health later on in life (F5, F9, F18, F41, F58, F69, F81, F121, F130, F133, F149). In a few cases screen time caused serious family conflicts between parents-children or between siblings so schedules, limits and 
time frames should be discussed and compromises mutually reached (F79, F130). On the other hand "a secret weapon" and "a big gun" were activities engaging children or teenagers manually, like stickers, coloring, painting, sewing, breads, play dough and clay, DIY projects, wooden crafts, pottery, old repairs. These often forgotten hands-on entertainments were considered a key to success. This arts-and crafts-time was also suitable to more or less engaging discussions and the communication could be held in different languages (to give more stimuli and to procure linguistic input).

Family sport and leisure activities were (re)discovered. With use of media, family workouts were recommended as a fun activity for the entire family.

\section{DISCUSSION}

As expected, each family is different and its case represents a different story. It is impossible, regrettably but inevitably, to generalize and formulate universal conclusions as the linguistic scenarios and circumstances in the multilingual families varied a priori and changed uncontrollably during the COVID-19 pandemic. Nevertheless, the results of the analyzed research material offer important insights into family multilingualism under those special unprecedented social circumstances. The outcome of this study can be a reference for future studies carried out by other researchers, especially in longitudinal perspective. We fully acknowledge that a follow-up study in - let's say - one year should be able to shed more light into the researched issue, especially in terms of the long lasting effects of the COVID-19 pandemic. The strength of the conducted research consists in putting together several specific recommendations, good and bad practices, and useful tips and advice for parents (or parents-to-be) who want to successfully raise their children with more than one language. It cannot be ruled out that at some point another pandemic will affect humanity (nor do we actually really know how long the present crisis will last). The effectiveness of the solutions "that work" depends, undoubtedly, on many internal (family-related) and external (environment-related) factors.

It should be also highlighted that the study is based on a convenience sample which is undoubtedly not representative - even the way that the parents were recruited suggests that we talk about adults using technology and possessing devices that enable the use of internet. Many families were left out due to financial and technological limitations and were not able to provide all needed support to their children (and many immigrant families, who might have been particularly affected in this regard, are multilingual!). There is also another aspect that requires a mention: in the present paper we focused on the narrow aspect of the daily life during the pandemic as we concentrated on the language issues. There seems to be a rather positive overall picture of the situation emerging from the data collected from families recruited on the basis of self-selection. Staying with family members under the same roof for a prolonged period of time was however for sure challenging and not "all roses", and there were unpleasant moments to deal with as well as the pleasant ones. We did not 
try to disregard the adverse outcomes of the long haul isolation and the necessity to strive with negative consequences of the pandemic, but this issue simply falls beyond the scope of this article.

\section{CONCLUSIONS}

The present paper offers an exploration of the topic of raising multilingual children in the challenging and unprecedented times of the COVID-19 pandemic. The health emergency related to the coronavirus' world-wide spread and the consequent restrictive measures and lockdowns have significantly changed the lifestyles and daily routines of many families, including those multilingual ones. Parents with children had to face an unprecedented and completely new situation in which they suddenly remained the only reference point for their children and 24/7 caregivers with professional work responsibilities, house chores, child care duties, and academic tasks and commitments during the school closures. The study was conducted via an online survey during the month of February 2021, 10-11 months after the pandemic began, and lockdowns and other restriction first started. The most important effects of the COVID-19 pandemic on multilingual families were illustrated and discussed. We addressed the evaluation of the impact of the safety measures on the linguistic situation at home, ways to adapt to the new circumstances due to quarantining, stay-at-home orders, self isolation, social distancing, school closures, switching to remote learning, travel bans, and other restrictions in context of the necessity of changing the family language policy, implementing new strategies, finding alternative and additional educational resources, coping with new challenges, commitments, tasks, needs and difficulties. We gathered some advice, recommendations, good practices, helpful ideas and valuable tips voiced by the interviewed parents. The findings of the study may be of theoretical interest to linguists researching different aspects of multilingualism, and of practical interest to parents raising, or planning to grow, a multilingual family.

\section{REFERENCES}

Aronin, L., and D. Singleton. 2008. "Multilingualism as a new linguistic dispensation”, International Journal of Multilingualism 5: 1-16.

Baker, C. 2014. A parents' and teachers 'guide to bilingualism. Bristol, Buffalo, Toronto: Multilingual Matters.

Barron-Hauwaert, S. 2011. Bilingual Siblings: Language Use in Families (Parents' and Teachers' Guide). Bristol, Buffalo, Toronto: Multilingual Matters.

Bhatia, T.K., and W.C. Ritchie. 2013. "Introduction". In The Handbook of Bilingualism and Multilingualism, eds. T.K. Bhatia, and W.C. Ritchie. New York: Wiley Blackwell Publishing, xxi-xxiii.

Braun, A., and T. Cline. 2014. Language Strategies for Trilingual Families: Parent's perspectives. Bristol, Buffalo, Toronto: Multilingual Matters.

Ceroz, J. 2013. Defining Multilingualism, Annual Review of Applied Linguistics 3: 3-18. 
Edwards, J. 2013. "Bilingualism and Multilingualism: Some central conceptions". In The Handbook of Bilingualism and Multilingualism, eds T.K. Bhatia, and W.C. Ritchie. New York: Wiley Blackwell Publishing, 5-25.

Franceschini, R. 2013. "History of Multilingualism". In The encyclopedia of applied linguistics, ed. C.A. Chapelle. New York: Blackwell Publishing, 4-8.

Festman, J., G.J. Poarch, and J.M. Dewaele. 2017. Raising multilingual children. Bristol, Buffalo, Toronto: Multilingual Matters.

Hardach, S. 2020. “Quarantine, Kids Pick Up Parents' Mother Tongues”. https://www.nytimes.com/2020/09/10/ parenting/family-second-language-coronavirus.html (October 26, 2021).

King, K., and A. Mackey. 2009. The bilingual edge: Why, when, and how to teach your child a second language. Harper Collins.

Morelli, M., E. Cattelino, R. Baiocco, C. Trumello, A. Babore, C. Candelori, and A. Chirumbolo. 2020. "Parents and children during the covid-19 lockdown: the influence of parenting distress and self-efficacy on children's emotional well-being". https://doi.org/10.3389/fpsyg.2020.584645 (October 26, 2021).

Murrmann, J. 2019. "Rodzinna polityka językowa: Strategie komunikacyjne w wychowywaniu dzieci trójjęzycznych" ["Family Language Policy. Communication Strategies in Raising Trilingual Children”]. https://doi.org/10.17651/SOCJOLING.33.12 (October 26, 2021).

Serratrice, L. 2020. "Languages in Lockdown: Time to think about multilingualism”. http://www.lucid.ac.uk/ news-events-blog/blogs/languages-in-lockdown-time-to-think-about-multilingualism/ (October 26, 2021). Spolsky, B. 1998. Sociolinguistics. Oxford: Oxford University Press.

Stavans, A., and Ch. Hoffmann. 2015. Multilingualism: Key topics in sociolinguistics, Cambridge: Cambrigde University Press.

Wang, X. 2008. Growing up with three languages: Birth to Eleven. Bristol, Buffalo, Toronto: Multilingual Matters.

Wang, X. 2016. Maintaining three languages: The teenage years. Bristol, Buffalo, Toronto: Multilingual Matters.

Zurer Pearson, B. 2008. Raising a bilingual child. New York: Living Language.

\section{Wpływ pandemii na sytuację rodzin wychowujących dzieci wielojęzycznie z perspektywy socjolingwistycznej}

Słowa kluczowe: wielojęzyczność, pandemia, kompetencje lingwistyczne, rodzina.

\section{STRESZCZENIE}

Bezprecedensowa sytuacja zaistniała na całym świecie w związku z rozprzestrzenianiem się koronawirusa oraz wynikające z tego wprowadzenie środków bezpieczeństwa zmieniły pod wieloma względami sytuację rodzin wychowujących dzieci wielojęzycznie. Na podstawie badań empirycznych przeprowadzonych na 157 rodzinach w artykule przedstawiono wpływ pandemii koronawirusa na życie rodzin wielojęzycznych z perspektywy socjolingwistycznej. Jeśli chodzi o wstępną ocenę oddziaływania globalnej epidemii na sytuację językową $\mathrm{w}$ domu, to 68 badanych rodzin stwierdziło, że pandemia koronawirusa miała ogólnie pozytywny wpływ na 
znajomość języków używanych przez dzieci, 49 rodzin zaobserwowała raczej negatywne konsekwencje dla rozwijania języków w domu, 33 spośród badanych rodziców nie zauważyło żadnych znaczących różnic we władaniu językami używanymi w życiu danej rodziny, natomiast 7 rodzin nie potrafi jeszcze określić, jak podsumować okres pandemii w kontekście poprawy lub pogorszenia znajomości poszczególnych języków przez dzieci. Należy podkreślić, że sytuacja każdej rodziny była inna i w związku z tym różniły się sposoby radzenia sobie z ograniczeniami wynikającymi z zakazu przemieszczania się, zamknięcia szkół i przejścia na nauczanie zdalne, przedłużającej się izolacji społecznej, ograniczeń w podróżowaniu i innych obostrzeń. W wielu przypadkach konieczne było wprowadzenie nowej rodzinnej polityki językowej, zmiana strategii i metod dotychczas wykorzystywanych, użycie alternatywnych i dodatkowych materiałów edukacyjnych. Opisano strategie radzenia sobie $\mathrm{z}$ trudnościami, wyzwaniami, nowymi potrzebami i zadaniami, a także z kwestiami organizacyjno-emocjonalnymi powstałymi ze względu na pandemię. Na podstawie analiz udało się zebrać cenne wskazówki i dobre praktyki, które wykorzystywali przebadani rodzice. Wyniki badań mogą zainteresować zarówno językoznawców zajmujących się różnymi aspektami wielojęzyczności jak i rodziców wychowujących lub planujących wychować dzieci wielojęzycznie. 